\title{
Pelatihan Pembuatan Blog untuk Pengembangan Media Pembelajaran di Sekolah Menengah Atas dan Kejuruan
}

\author{
Vitri Tundjungsari ${ }^{1}$, Suhaeri $^{2}$ \\ ${ }^{1,2}$ Fakultas Teknologi Informasi, Universitas YARSI \\ Jl. Letjen Suprapto, Jakarta Pusat \\ ${ }^{1}$ vitri.tundjungsari@yarsi.ac.id
}

\begin{abstract}
Weblog or also called a blog is a tool to write and inform the online activities of a person/persons or an organization. A blog can also be used by the education institution to spread the information of learning process activities between teachers and students. This paper reports blog training to support learning process activities for teachers and students at SMK Ristek Jaya and SMA Muhammadiyah 1 located in Jakarta. The training is part of our community service empowerment and has purposed to enable the learning process from anywhere so then the learning materials can be accessed online anywhere and anytime. The result of testing shows that post-test result is higher than pre-test result. This can be concluded that all of the participants in the training have significant improvement in blog usage and knowledge. The testing result also shows that blog is potential to be used as the learning tool in high schools. However, the effectiveness of the learning process using the blog should be examined further.
\end{abstract}

Keywords: Blog; Education, Learning tool, Community empowerment

\begin{abstract}
ABSTRAK
Weblog atau disebut juga sebagai blog merupakan sarana untuk menuliskan dan menginformasikan aktivitas seseorang maupun organisasi secara online. Blog dapat digunakan institusi pendidikan untuk penyebaran informasi maupun kegiatan belajar-mengajar antara guru dan murid. Pelatihan ini ditujukan untuk para guru dan murid SMK Ristek Jaya dan SMA Muhammadiyah 1 Jakarta guna membantu kegiatan belajar-mengajar sehingga materi pembelajaran dapat diakses dari mana saja. Hasil pelatihan menunjukkan bahwa seluruh peserta mengalami kenaikan pengetahuan yang signifikan, ditunjukkan dengan hasil post-test yang lebih tinggi dibandingkan dengan hasil pre-test. Hasil pelatihan juga menunjukkan bahwa blog berpotensi untuk dijadikan sebagai media pembelajaran di sekolah. Namun demikian, masih perlu diteliti lebih lanjut efektivitas pembelajaran dengan blog.
\end{abstract}

Kata kunci: Blog, Pendidikan, Media pembelajaran, Pengabdian masyarakat

\section{PENDAHULUAN}

Internet saat ini tidak hanya digunakan sebagai sumber informasi tetapi juga sebagai sarana komunikasi dan penyebaran informasi yang sangat dibutuhkan di berbagai bidang, termasuk bidang pendidikan. Internet memberikan peranan yang sangat penting bagi pendidikan karena melalui internet, informasi dan referensi akan sangat mudah didapat sehingga pembelajaran berbasis internet dapat dimanfaatkan. Data dari APJII menyebutkan bahwa pengguna internet di Indonesia sudah mencapai angka 88,1 juta (Tim APJII, 2016). Jika dibandingkan dengan 252,4 juta penduduk Indonesia, dapat dikatakan bahwa penetrasi pengguna internet di negara ini mencapai $34,9 \%$. Angka tersebut meningkat cukup banyak bila dibandingkan dengan tahun 2013, penetrasi internet baru mencapai $28,6 \%$. Hal ini menunjukkan bahwa pengguna internet Indonesia bertambah dengan sangat cepat.

Weblog atau disebut juga dengan blog, merupakan salah satu manfaat yang bisa diambil dari internet. Blog saat ini menjadi alternatif baru bagi publikasi melalui internet. Bukan hanya untuk instansi, tapi juga untuk publikasi pribadi. Mengelola sebuah blog adalah sebuah kegiatan yang mudah dilakukan oleh setiap orang, mulai dari pelajar, mahasiswa, dosen, karyawan, dan siapa saja. Untuk membuat dan mengelola blog tidak diperlukan keahlian programming khusus di bidang komputer, sehingga blog mudah dipelajari oleh siapa pun. Karenanya, pelatihan pembuatan 
blog untuk memanfaatkan blog sebagai media pembelajaran di sekolah diberikan. Pelatihan ini diharapkan dapat meningkatkan kualitas dan keilmuan siswa dan siswi SMA/SMK melalui pemanfaatan blog untuk pembelajaran. Selain itu, pelatihan ini juga memberikan keahlian baru dalam menguasai teknologi informasi, khususnya blog dan web. Blog yang dihasilkan melalui pelatihan ini diharapkan dapat dijadikan media pembelajaran untuk berbagi informasi dan materi pembelajaran, sekaligus menyediakan informasi mengenai profil sekolah dan kegiatan belajarmengajar di SMA/SMK.

Blog merupakan sebuah situs web yang terdiri atas serangkaian entri yang berurutan yang sering diperbarui dengan informasi tentang topik-topik tertentu. Informasi tersebut dapat ditulis oleh pemiliknya langsung maupun sumber lain (Rouse, 2007). Menurut Computer Glossary of Terms, sebuah blog pada dasarnya merupakan sebuah jurnal yang tersedia di internet. Aktivitas yang dilakukan pada blog disebut dengan aktivitas blogging, sedangkan orang yang melakukan aktivitas blogging disebut dengan seorang blogger. Tujuan blog secara umum yaitu menyampaikan informasi yang bermanfaat untuk diri sendiri maupun bagi orang orang lain.

Blog memiliki keunggulan dibandingkan saluran komunikasi lainnya (Adri, 2008):

1) Publishable. Blogger dapat langsung mem-posting berita dengan murah, mudah, dan dapat dibaca di mana pun.

2) Findable. Mudah ditemukan lewat situs pencari berdasarkan subjek, nama penulis, atau keduanya. Semakin lengkap dan terkini informasi pada suatu blog, biasanya semakin digemari.

3) Social. Blog menyediakan informasi dan diskusi menarik berdasarkan topik yang dapat beralih dari satu situs ke situs web lain, menghubungkan dari suatu link ke link lain. Melalui blog, mereka yang memiliki minat yang sama dapat membangun komunitas dan jaringan tanpa batas waktu dan letak geografis.

4) Viral. Informasi menyebar lebih cepat melalui blog dibanding surat kabar.

5) Syndicatable. Blog memiliki konten yang kaya dan mudah dikendalikan dan didapatkan oleh siapa saja.

6) Linkable. Blog terhubung dengan informasi lain yang tersedia di internet serta menyediakan komunikasi internet dua arah.

Walaupun blog memiliki keunggulan sebagaimana yang telah disebutkan, pemanfaatan blog sebagai media belajar masih belum banyak digunakan oleh guru dan siswa (Sudrajat \& Zulkarnain, 2013). Padahal, media ini sangat menarik untuk diterapkan di dalam kegiatan belajar. Kegiatan belajar dengan media blog dalam dunia pendidikan dapat meningkatkan kualitas diri dan kompetensi seorang guru karena memungkinkan seorang guru dapat bertukar pikiran dengan guru lain mengenai kiat-kiat mengajar. Selain itu, dengan media blog, guru dapat mengirim posting bahan ajar yang kemudian dapat dipelajari oleh siswa melalui blog ini. Selain bermanfaat bagi guru, blog juga bermanfaat bagi siswa. Siswa dapat belajar di luar jam sekolah tanpa ada batas ruang dan waktu, sekaligus memperkenalkan siswa pada dunia teknologi dan informasi. Sebagai media belajar, siswa juga dapat saling bertukar pikiran atau pendapat dengan teman satu kelas melalui komentar yang telah disediakan di dalam blog.

\section{METODE PELAKSANAAN}

Dalam kegiatan pengabdian masyarakat ini, peserta pelatihan diberikan materi-materi sebagai berikut.

1) Konsep pemanfaatan weblog dalam penyebaran informasi di bidang pendidikan

2) Pengenalan blog yang akan digunakan (dengan Wordpress)

3) Praktik cara menggunakan blog secara dasar

4) Praktik cara mengisi konten dalam blog, berupa: teks, gambar, maupun video

5) Praktik cara me-manage tampilan blog agar lebih menarik.

Materi-materi tersebut diberikan dalam dua kali pertemuan. Masing-masing pertemuan berdurasi selama kurang lebih empat jam. Materi untuk peserta diberikan dalam bentuk modul pelatihan. Tabel 1 menunjukkan materi yang diberikan dalam pelatihan ini. 
Mitra kegiatan dalam kegiatan pelatihan ini ialah SMA dan SMK swasta di wilayah Jakarta Pusat. Mitra bertugas untuk menyiapkan peserta dalam acara pelatihan, sedangkan pihak pengusul bertugas untuk menyiapkan materi pelatihan, sarana, dan prasarana pelatihan.

Pelatihan ini menerapkan evaluasi yang dilakukan sebanyak dua kali, dalam bentuk pre-test dan post-test (soal test dapat dilihat pada Tabel 2):

1. Evaluasi pertama dilakukan pada pertemuan pertama dengan memberikan pre-test. Pre-test ini bertujuan untuk mengetahui dan mengukur pengetahuan peserta pelatihan tentang blog.

2. Evaluasi kedua berupa post-test, dilakukan pada pertemuan terakhir, setelah semua materi pelatihan diberikan. Post-test ini dilakukan untuk mengukur pengetahuan peserta pelatihan setelah pelatihan diberikan.

Tabel 1. Materi Pelatihan Pembuatan Blog untuk Media Pembelajaran

\begin{tabular}{cllll}
\hline No. & Materi & Pengajar & Metode Pengajaran & $\begin{array}{l}\text { Pertemuan } \\
\text { ke- }\end{array}$ \\
\hline 1 & $\begin{array}{l}\text { Konsep pemanfaatan blog dalam } \\
\text { penyebaran informasi }\end{array}$ & $\begin{array}{l}\text { Dosen dan } \\
\text { Mahasiswa }\end{array}$ & Pengajaran tatap muka & 1 \\
2 & Pengenalan blog & $\begin{array}{l}\text { Dosen dan } \\
\text { Mahasiswa }\end{array}$ & $\begin{array}{l}\text { Pengajaran tatap muka, } \\
\text { demo, praktik }\end{array}$ & 1 \\
3 & Praktik dasar membuat blog & $\begin{array}{l}\text { Dosen dan } \\
\text { Mahasiswa }\end{array}$ & Demo dan praktik & 1 \\
4 & $\begin{array}{l}\text { Praktik mengisi konten dalam } \\
\text { blog (teks, gambar, video) }\end{array}$ & $\begin{array}{l}\text { Dosen dan } \\
\text { Mahasiswa }\end{array}$ & Demo dan praktik & 2 \\
5 & $\begin{array}{l}\text { Praktik me-manage tampilan } \\
\text { blog agar lebih menarik }\end{array}$ & $\begin{array}{l}\text { Dosen dan } \\
\text { Mahasiswa }\end{array}$ & Demo dan praktik & 2 \\
\hline
\end{tabular}

Tabel 2. Daftar Pertanyaan dalam Pre-test dan Post-test

\begin{tabular}{ll}
\hline No. & Pertanyaan \\
\hline 1 & Blog adalah: \\
& a) Postingan yang menampilkan informasi atau diskusi melalui web \\
& b) Postingan yang menampilkan nama dan alamat di media sosial \\
& c) Postingan yang menampikan lokasi suatu tempat di peta \\
\hline 2 & Berikut ini merupakan contoh aplikasi blog, kecuali: \\
a) BlogSpot \\
b) Wordpress \\
c) Instagram \\
\hline 3 & Blog dapat dibuat secara gratis oleh: \\
& a) Single individual/perorangan \\
b) Organisasi tertentu \\
c) Semua jawaban benar \\
\hline 4 & Bahasa pemrograman yang digunakan untuk membangun aplikasi Wordpress adalah: \\
& a) Java \\
b) Python \\
c) PHP \\
\hline 5 & Database yang digunakan untuk menyimpan data dalam aplikasi Wordpress adalah: \\
& a) Oracle \\
b) MySQL \\
c) Microsoft Access \\
\hline 6 & Nama unik yang diberikan untuk mengidentifikasi alamat (IP address) server komputer seperti \\
server web atau server email di internet, disebut sebagai: \\
a) Domain \\
b) Hosting \\
c) Web \\
\hline 7 & Berikut ini merupakan contoh nama top level domain: \\
a) com \\
b) sch \\
c) Semua jawaban benar \\
\hline
\end{tabular}




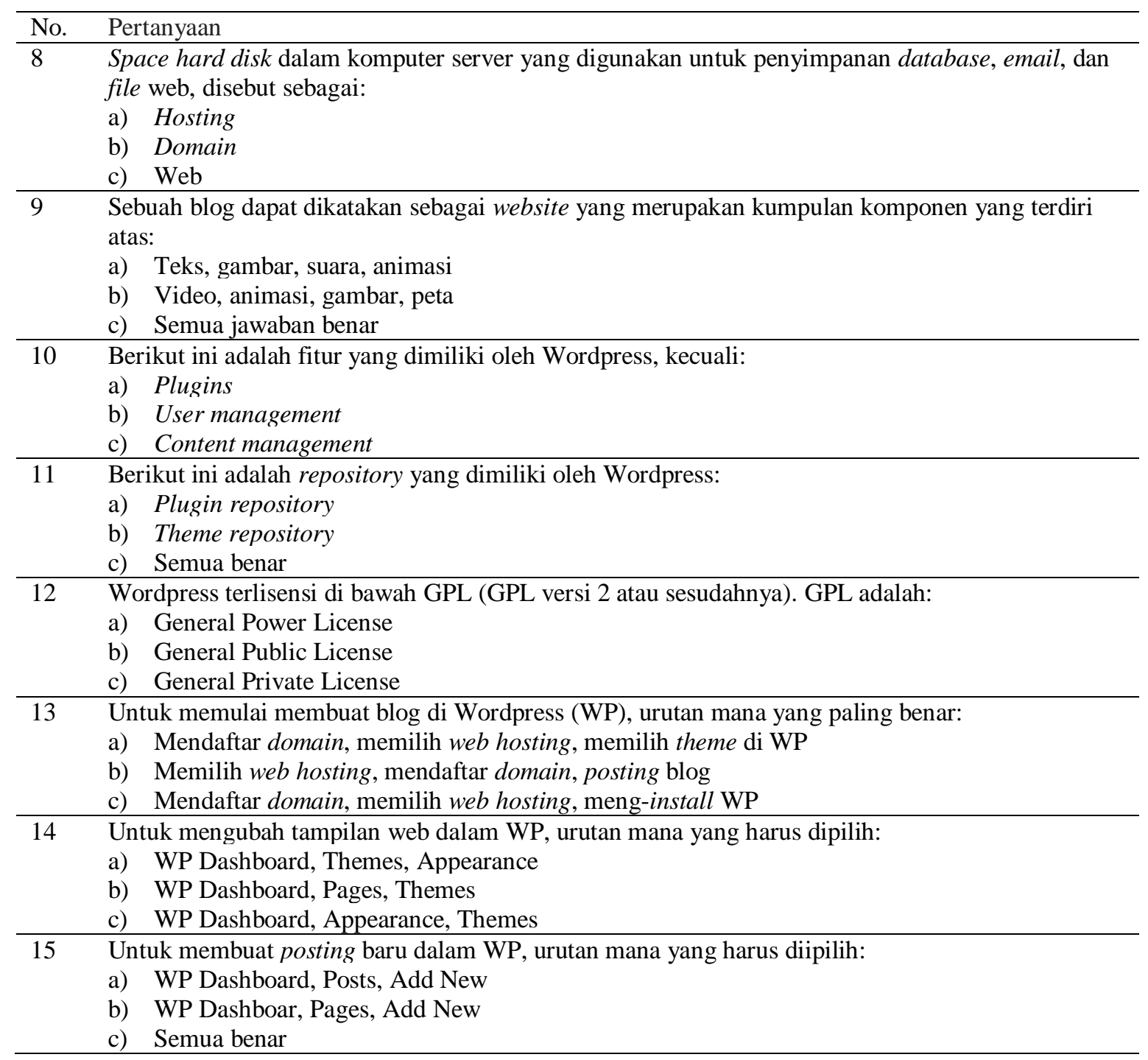

\section{HASIL DAN PEMBAHASAN}

Peserta dalam pelatihan ini terdiri atas 15 guru dan murid (5 orang guru dan 10 orang murid) yang berasal dari dua sekolah menengah atas dan kejuruan di wilayah Jakarta Pusat. Penilaian pre-test dan post-test dilakukan dengan memberi skor 100 untuk setiap jawaban benar yang kemudian dijumlahkan lalu dibagi dengan jumlah soal (15 soal). Pada Gambar 1 diperlihatkan grafik batang hasil pre-test dan post-test dari seluruh peserta pelatihan yang berjumlah 15 orang. Dari hasil pre-test dan post-test dapat dilihat bahwa seluruh peserta mengalami peningkatan pengetahuan. Hal ini terlihat dari nilai rata-rata pre-test sebesar 55 dan post-test sebesar 86.

Setiap peserta pelatihan diharuskan membuat blog yang kemudian dinilai oleh tim pelatih. Pelatih terdiri atas dosen dan mahasiswa Universitas YARSI. Peserta dengan nilai tertinggi mendapatkan hadiah dari tim pelatih. Kriteria penilaian terdiri atas: (1) kejelasan petunjuk penggunaan blog, (2) kejelasan menu/struktur blog, (3) desain blog yang menarik dan user friendly, (4) adanya interaksi antara penulis blog dan pengguna atau antar pengguna lainnya, (5) memuat konten yang up-to-date dan valid, (6) Keragaman materi dalam blog, (7) kebahasaan, serta (8) tata tulis.

Peserta pelatihan juga diminta untuk menilai komponen-komponen apa yang terpenting dalam menggunakan blog untuk media pembelajaran. Setiap peserta memberikan preferensinya untuk memberi nilai terhadap komponen terpenting dalam pembuatan blog. Penilaian menggunakan skala 5, dengan skor minimal 1 dan skor maksimal 5. Hasil penilaian menghasilkan 6 komponen penting dengan skor rerata di atas 4, sebagaimana ditunjukkan pada Tabel 3. 


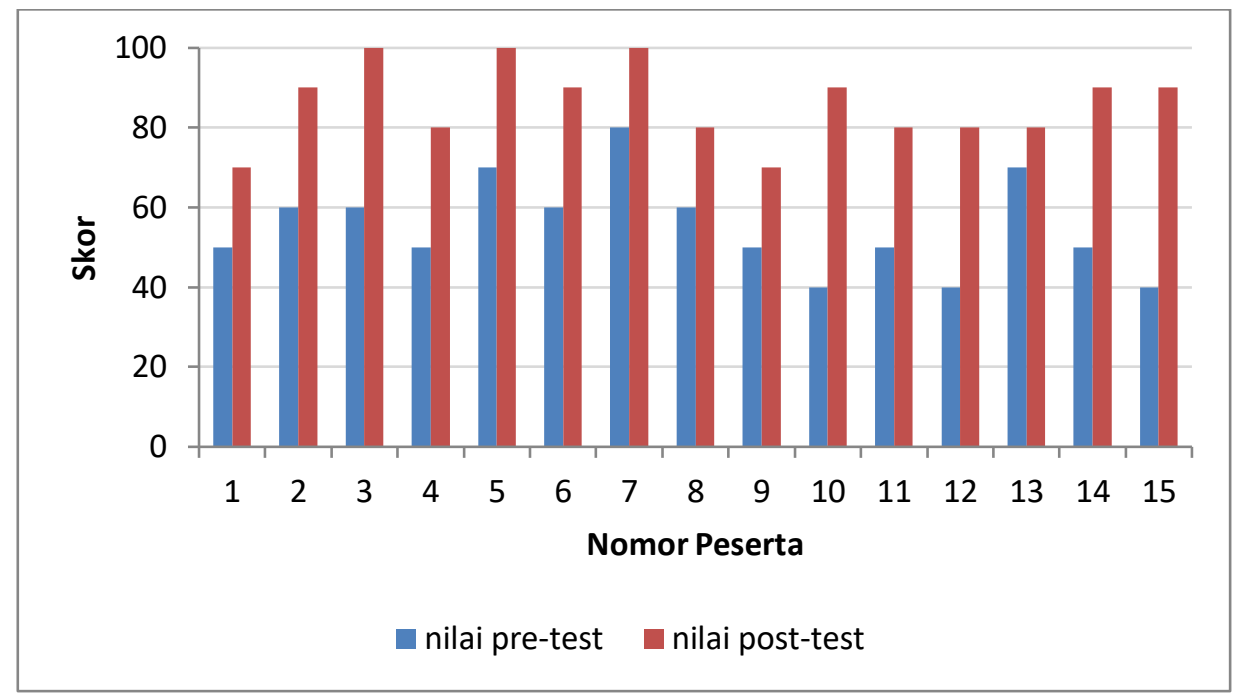

Gambar 1. Hasil Pengujian Pre-test dan Post-test Peserta Pelatihan

Tabel 3. Komponen Terpenting dalam Sebuah Blog Menurut Peserta Pelatihan

\begin{tabular}{rlr}
\hline No & Komponen Penilaian & Rerata Skor \\
\hline 1 & Kejelasan menu/struktur blog & 4,73 \\
2 & Kejelasan petunjuk penggunaan untuk pembelajaran & 4,67 \\
3 & Desain blog yang menarik dan user-friendly & 4,60 \\
4 & Memuat konten yang up-to-date dan valid & 4,53 \\
5 & Bahasa baku dan mudah dimengerti & 4,33 \\
6 & Bentuk dan besar huruf (font) & 4,33 \\
\hline
\end{tabular}

Pada Tabel 3, dapat dilihat bahwa komponen dengan nilai tertinggi adalah kejelasan struktur blog (nilai rata-rata skor 4,73), berikutnya adalah kejelasan petunjuk penggunaan blog untuk pembelajaran, disusul dengan desain blog yang menarik dan user-friendly, konten up-to-date dan valid, penggunaan bahasa yang baku dan mudah dimengerti, serta kejelasan bentuk dan besar huruf (font) agar mudah dibaca.

Gambar 2 dan 3 berikut merupakan foto-foto saat pelatihan berlangsung, sedangkan gambar 4, 5, dan 6 merupakan contoh hasil blog dari para peserta pelatihan. Pelatihan dilaksanakan di laboratorium multimedia Universitas YARSI Jakarta.

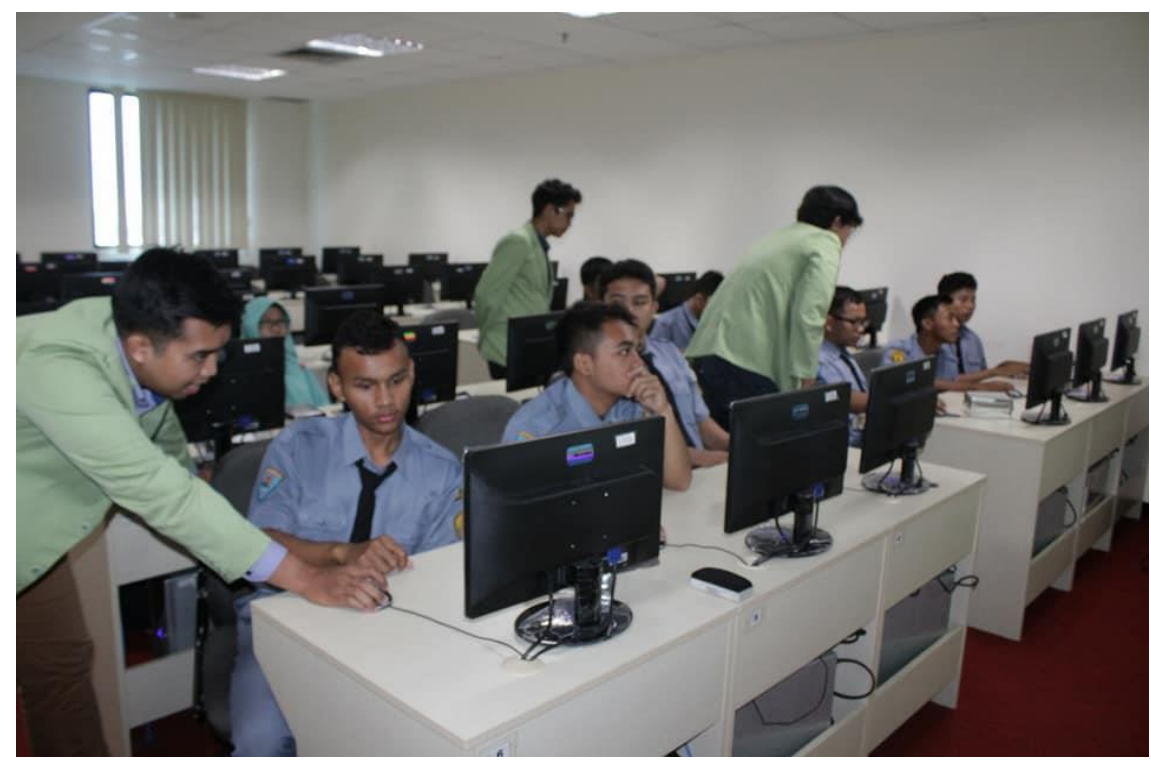

Gambar 2. Suasana Saat Pelatihan Berlangsung 


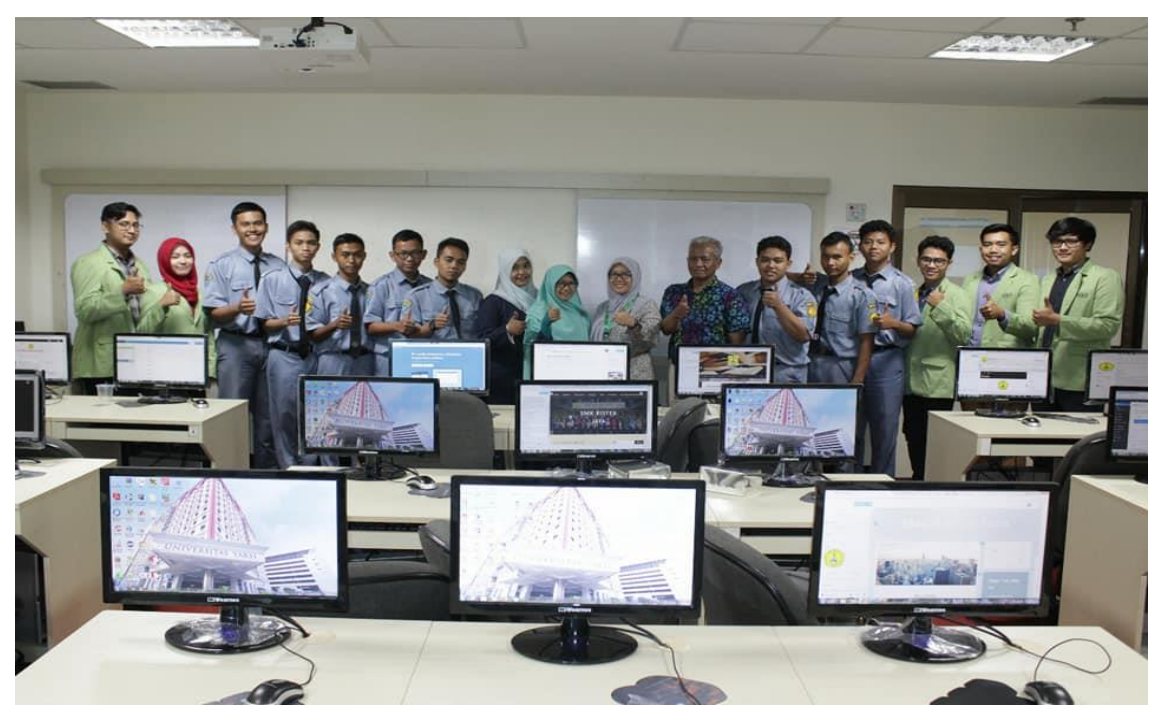

Gambar 3. Pelatih dan Peserta Pelatihan

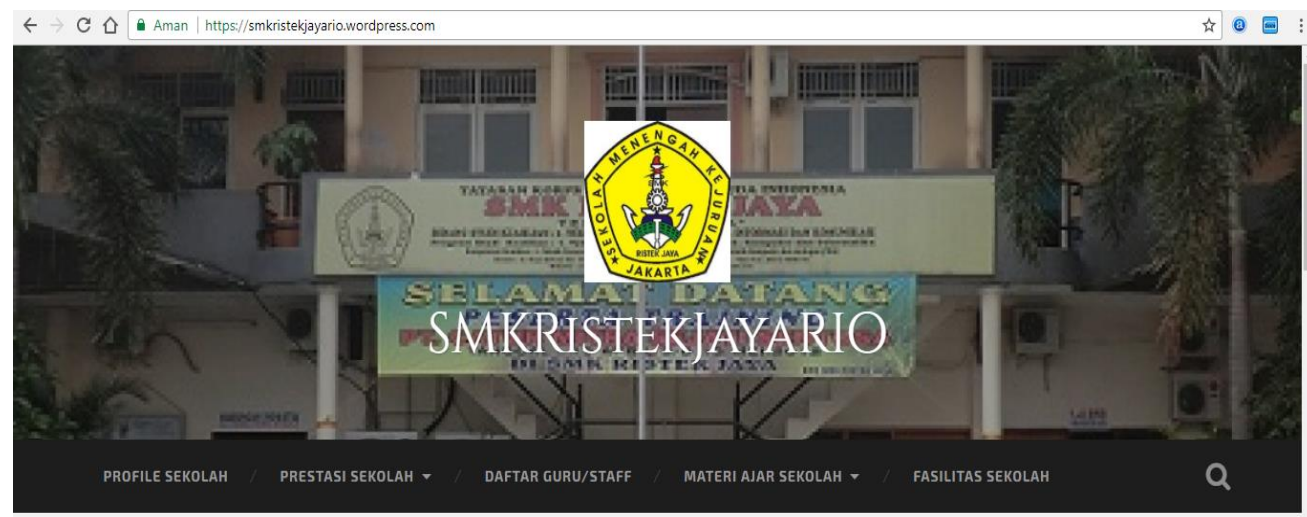
KEGIATAN TENTANG
KEGIATAN SHOLAT
EKSTRAKULIKULER
TAHAJUD

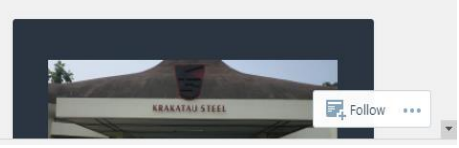

Gambar 4. Hasil Tampilan Blog Peserta Pelatihan (smkristekjayario.wordpress.com)

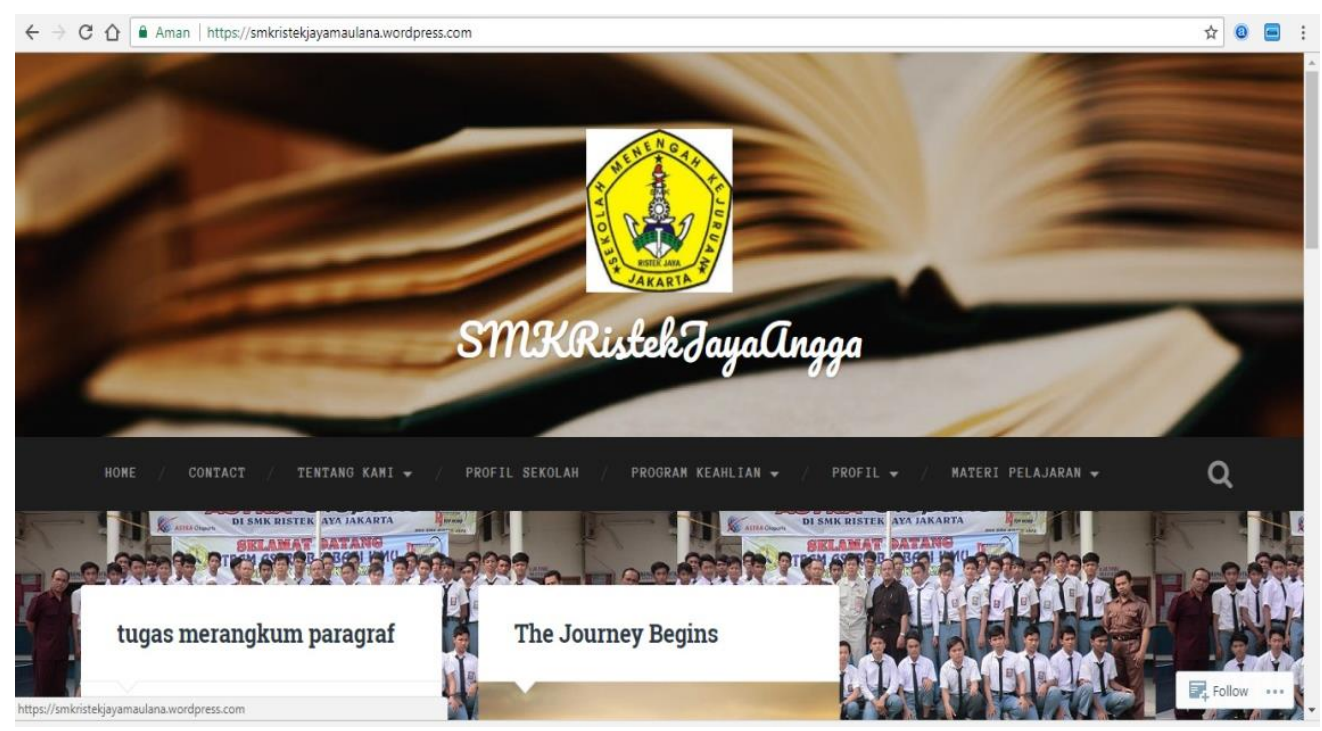

Gambar 5. Hasil Tampilan Blog Peserta Pelatihan (smkristekjayamaulana.wordpress.com) 


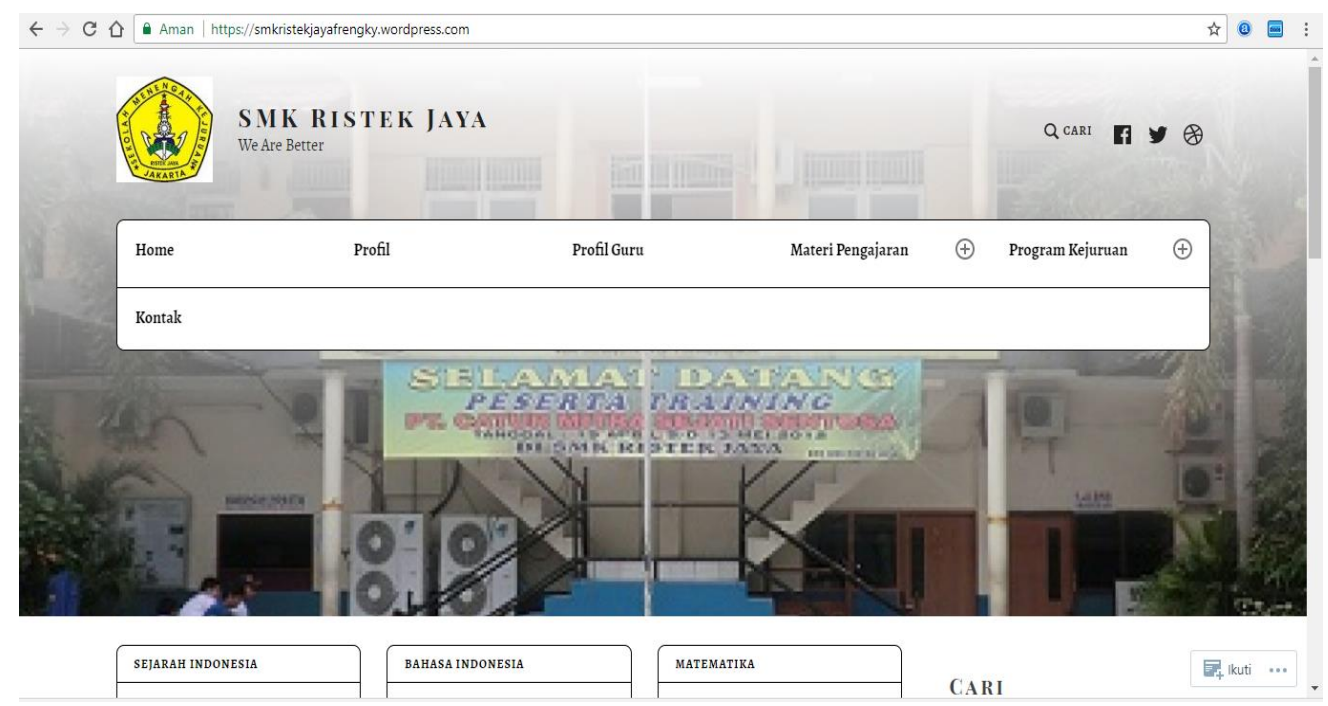

Gambar 6. Hasil Tampilan Blog Peserta Pelatihan (smkristekjayafrengky.wordpress.com)

\section{KESIMPULAN}

Pelatihan membuat blog dapat diberikan kepada masyarakat umum karena mudah dipahami. Hasil uji pre-test dan post-test dalam pelatihan ini menunjukkan terjadinya peningkatan pengetahuan yang signifikan dari peserta setelah pelatihan diberikan.

Blog juga memiliki potensi untuk dijadikan media pembelajaran asallkan dapat memenuhi komponen-komponen penting, seperti: memiliki struktur blog yang jelas, memiliki petunjuk pengggunaan blog untuk pembelajaran yang jelas, desain yang menarik dan user-friendly, memuat konten yang up-to-date, serta memiliki bahasa baku dan mudah dibaca.

Kegiatan pengabdian masyarakat ini dapat dikembangkan untuk sekolah-sekolah yang lain. Selain itu, perlu juga diteliti efektivitas media blog ketika diterapkan pada beberapa sekolah dengan karakteristik sekolah yang berbeda.

\section{DAFTAR PUSTAKA}

Adri, M. (2008). Guru Go Blog: Optimalisasi Blog Untuk Pembelajaran. Padang: Elex Media Komputindo.

Rouse, M. (2007, November). What is blog (weblog) ? Diambil dari https://searchwindevelopment .techtarget.com/definition/blog

Sudrajat, A., \& Zulkarnain, Z. (2013). Pengembangan Media Blog Sejarah sebagai Alternatif Media Pembelajaran Sejarah di Sekolah Menengah Atas (Laporan Penelitian dan Pengabdian kepada Masyarakat). Universitas Negeri Yogyakarta.

Tim APJII. (2016). Buletin APJII, Edisi 05 - November 2016 (hlm. 1-7). Jakarta: Asosiasi Penyelenggara Jasa Internet Indonesia. Diambil dari https://apjii.or.id/downfile/file /BULETINAPJIIEDISI05November2016.pdf 
JPP IPTEK, Mei 2018, Vol. 2, No. 1

Halaman ini sengaja dikosongkan 